\title{
Pembuatan Video Edukasi Vaksinasi Covid-19 Pada Civitas Akademika Universitas Muhammadiyah Mataram
}

\author{
COVID-19 Vaccination Education Video \\ For Civitas Academics in University of Muhammadiyah Mataram
Anna Pradiningsih ${ }^{1}$, Mahacita Andanalusia ${ }^{2}$, Baiq Leny Nopitasari ${ }^{3}$, Baiq Nurbaety $^{4}$, Alvi Kusuma Wardani ${ }^{5}$, Cyntiya Rahmawati ${ }^{6}$
Universitas Muhammadiyah Mataram, Kota Mataram, Indonesia. annapradiningsih@gmail.com, citaandanalusia@gmail.com

Riwayat Artikel: Dikirim 2 Juli 2021; Diterima 17 November 2021; Diterbitkan 30 November 2021

\begin{abstract}
Abstrak
Vaksin adalah produk biologis yang apabila diberikan kepada seseorang akan menimbulkan kekebalan spesifik secara aktif terhadap penyakit infeksi. Saat ini, Indonesia sedang melaksanakan program vaksinasi untuk COVID-19. Tujuan dari program vaksinasi ini adalah untuk mencegah penyebaran masif virus corona yang satu tahun terakhir menyebabkan pandemi. Ada beberapa tahapan dalam program vaksinasi berdasarkan sasaran masyarakat. Universitas Muhammadiyah Mataram sebagai institusi pendidikan yang memberikan pelayanan publik dengan civitas akademika di dalamnya merupakan sasaran tahapan kedua dalam program vaksinasi. Adanya keragaman bidang ilmu di lingkungan Universitas Muhammadiyah Mataram menyebabkan perbedaan pengetahuan dan pemahaman tentang vaksin. Oleh karena itu, perlu dilakukan edukasi untuk membantu civitas akademika dalam memahami pentingnya vaksin. Pada pengabdian ini, dilakukan edukasi melalui metode audio visual, yaitu video. Video dibuat dengan dua bahasa, yaitu Bahasa Indonesia dan Bahasa Inggris. Beberapa hal yang disampaikan di video antara lain definisi vaksin, jenis vaksin, mekanisme kerja vaksin, tujuan pemberian vaksin, pengenalan vaksin COVID-19, efek yang mungkin ditimbulkan setelah pemberian vaksin dan hal yang perlu dilakukan jika terdapat efek yang tidak diinginkan muncul. Video kemudian diunggah di internet dan disebarkan secara daring kepada civitas akademika. Melalui video edukasi, diharapkan civitas akademika dapat memperoleh pengetahuan mengenai pentingnya berpartisipasi dalam vaksinasi COVID-19.
\end{abstract}

Kata kunci: Edukasi, Video, Vaksin, Covid-19, Civitas akademika.

\begin{abstract}
$V$ accine is a biological product that used to stimulate the production of antibodies and provide immunity against infectious disease. In he beginning of 2021, Indonesia has started vaccination program for COVID-19. The main purpose of the program is to prevent the massive spread of corona virus, which has caused pandemic since December2019. There are some steps of vaccination program based on the community target. Muhammadiyah University of Mataram as a formal educational institution that gives public service to society is included in the second step of vaccination. However, the variety of field at the institution causes the knowledge differences about vaccine. Therefore, education to help civitas academics to understand more about vaccine was needed. Education was done by audio visual method or video. The videos were made with two language, Indonesian and English. Some contents that included in the video were vaccine definition, type of vaccine, vaccine's mechanism of action, vaccine's benefit, COVID19 vaccine, the possible effects after getting COVID-19 vaccine and how to overcome them. The videos was uploaded in the internet and distributed online to che civitas academics. Through this video, it is hoped that the civitas academics can understand the importance of their participation in COVID-19 vaccine.
\end{abstract}

Keywords: Education, Video, Vaccine, Covid-19, Civitas academics 


\section{PENDAHULUAN}

WHO telah menetapkan COVID-19 ditetapkan sebagai pandemic global sejak Maret 2020 (WHO, 2020). Dalam perkembangannya, wabah penyakit COVID-19 ini terjadi di Wuhan dan menyebar ke 210 negara (Worldometers, 2020). Penyebaran yang sangat cepat diantara manusia, ditambah dengan mobilitas manusia yang sangat tinggi dan lintas batas Negara, menjadikan virus ini lebih berbahaya. Dengan paparan COVID19 yang sangat cepat, diharapkan dapat ditemukkan vaksin untuk menghentikan laju paparan COVID-19 tersebut.

Vaksin telah lama dikenal sebagai suatu subtansi yang digunakan untuk memperoleh respon imun terhadap paparan mikroorganisme pathogen khususnya virus. Vaksin pertama kali ditemukan oleh Edward Jenner pada tahun 1796 . Virus yang pertama ditemukan adalah virus cacar. Sejak saat itu teknologi pembuatan vaksin semakin berkembang pesat dan berbagai jenis vaksin telah banyak digunakan (Radji, 2009).

Pada awal Desember 2020, Indonesia telah menerima 3 juta dosis vaksin COVID19 Sinovac. Vaksin tersebut mulai didistribusikan ke sejumlah daerah di Indonesia. Pelaksanaan vaksinasi akan dilkaukan sesuai dengan ijin BPOM yang diperkirakan akan dilakukan pada 15-25 Januari 2021. Di beberapa daerah seperti di Sulawesi Selatan dan Sumatera Selatan vaksinasi akan dilakukan pada 14 Januari 2021 diutamakan vaksinasi dilakukan kepada kepala daerah dan tokoh masyarakat. Sedangkan di Bali vaksinasi diperkirakan akan dilakukan pada 22 Januari 2021, vaksinasi diutamakan dilakukan pada seluruh tenaga kesehatan. Tahapan 1 vaksinasi (Januari-April 2021) memiliki sasaran vaksinasi antara lain tenaga kesehatan, asisten tenaga kesehatan, tenaga penunjang serta mahasiswa yang sedang menjalani pendidikan profesi kedokteran yang bekerja pada Fasilitas Pelayanan Kesehatan (Fasyankes). Tahap 2 (JanuariApril 2021) memiliki sasaran petugas pelayanan public dan kelompok usia lanjut. Tahap 3 (April 2021-Maret 2022) memiliki sasaran masyarakat rentan dari aspek geospasial, social dan ekonomi. Tahap 4 (April 2021-Maret 2022) memiliki sasaran pada masyarakat dan pelaku perekonomian lainnya dengan penedekatan kluster sesuai dengan ketersediaan vaksin.

Universitas Muhammadiyah Mataram merupakan salah satu institusi akademika yang berhubungan langsung dengan peserta didik. Interaksi antar individu dalam institusi ini sangat tinggi sehingga memungkinkan terjadi paparan antara satu orang ke orang lainnya. Oleh karena itu pada Vaksinasi Tahap 2 periode Januari-April 2021 ini sasaran pada pelayanan public akan mendapatkan vaksinasi COVID-19. Pelayanan public yang dimaksud antara lain institusi pendidikan dan civitas akademika yang terkandung di dalamnya. Untuk kelancaran pemberian vaksinasi ini maka perlu ditingkatkan pengetahuan tentang vaksinasi ini. Tingkat pengetahuan masyarakat akan pentingnya vaksinasi masih perlu ditingkatkan. Hal ini sehubungan dengan akan dilakukan vaksinasi nasional untuk COVID-19 ini, maka masyarakat perlu diberikan edukasi tentang pengertian vaksin dan tujuan penggunaan vaksin tersebut. Sejalan dengan program pemerintah mengenai vaksin, maka dilakukan vaksinasi dengan sasaran civitas akademika Universitas Muhammadiyah Mataram pada hari Jumat dan Sabtu, 19 - 20 Maret 2021 di Puskesmas Mataram.

Pada lingkungan kampus Universitas Muhammadiyah Mataram memiliki bidang ilmu yang heterogen dan tidak semuanya berasal dari bidang kesehatan sehingga untuk meningkatkan pengetahuan tentang kesehatan khususnya vaksinasi dapat dilakukan dengan pemberian edukasi. 
Edukasi yang diberikan dengan metode ceramah, saat ini sudah mulai ditinggalkan. Sehingga perlu dilakukan pendekatan yang keratif agar civitas akademika khususnya mahasiswa dapat memiliki ketertarikan dalam menerima edukasi tersebut. Edukasi kreatif di masa pandemic salah satunya adalah dengan membuat video edukasi. Video edukasi bertujuan untuk meningkatkan pemahaman masyarakat terkait vaksinasi secara audio visual.

Video edukasi vaksin ini membantu menjelaskan secara sederhana tentang Definisi vaksin, jenis vaksin, mekanisme kerja vaksin, tujuan pemberian vaksin, pengenalan vaksin COVID-19, efek yang mungkin ditimbulkan setelah pemberian vaksin dan hal yang perlu dilakukan jika terdapat efek yang mungkin ditimbulkan. $\mathrm{Hal}$ ini berujuan agar meningkatkan pemahaman dan kesadaran untuk vaksinasi di lingkungan civitas akademika Universitas Myhammadiyah Mataram.

\section{METODE}

Metode pelaksanaan pada peneletian ini dibagi menjadi beberapa tahapan. Langkah pelaksanaan kegiatan antara lain:

1. Pra Kegiatan

Pada tahap ini, tim pengabdian masyarakat melakukan persiapan pra kegiatan, hal ini dimaksudkan agar kegiatan dapat berjalan sesuai dengan perencana awal sesuai target dan sasaran kegiatan. Tahapan yang dilakukan pada pra kegiatan antara lain :

a. Pemilihan kelompok sasaran

Kelompok sasaran yang dipilih merupakan civitas akademika di Universitas Muhammadiyah Mataram. Hal ini dikarenakan civitas akademika merupakan pelayan public yang secara langsung akan memiliki interaksi antar individu yang cukup tinggi. Sehingga sangat perlu melakukan vaksinasi, oleh karena itu edukasi mengenai vaksinasi penting dilakukan pada kelompok sasaran ini.

b. Proses pembuatan video melalui aplikasi InShot

Pembuatan video dibagi menjadi dua bahasa yaitu bahasa Indonesia dan Bahasa Inggris. Pembuatan video ini diawali dengan membuat rancangan gambar item animasi yang dijadikan media dalam pemberian edukasi. Setelah mendapatkan gambar item animasi maka proses selanjutnya adalah mengedit gambar tersebut menjadi sebuah video dengan edukasi yang utuh. Hal ini dilakukan dengan menggunakan aplikasi InShot. Setelah itu, pemberian teks guna untuk memudahkan mitra dalam memahami video edukasi. Pada video Bahasa Indoensia akan diberikan teks Bahasa Indonesia, sedangkan untuk video Bahasa Inggris akan diberikan teks menggunakan Bahasa Inggris. Proses akhir dilakukan rekaman suara yang akan menjelaskan secara detail edukasi vaksinasi tersebut. Video dengan Bahasa Indonesia akan direkam menggunakan bahasa Indonesia. Sedangkan video dengan Bahasa Inggris akan direkan menggunakan bahasa Inggris.

c. Penyimpanan video yang akan didistribusikan

Hasil video akan di simpan pada perangkat elektronik sehingga akan mudah dalam proses pendistribusian.

2. Pelaksanaan Kegiatan

Video yang telah siap didistribusikan, kemudian diupload pada channel youtube Fakultas Ilmu Kesehatan Universitas Muhammadiyah Mataram. Setelah itu, link tersebut akan dibagikan melalui grup whatsapp pada lingkungan Universitas Muhammadiyah Mataram. Setiap anggota tim peneliti akan mengirimkan link ke grup yang berbeda agar link dapat tersebar secara merata. 


\section{Pasca Kegiatan}

Pada tahapan pasca kegitan dilakukan monitoring dan evaluasi hasil dari pendistribusian video edukasi yang telah dibagikan. Saran dan masukkan menjadi salah satu indikator evaluasi dari kegiatan ini.

a. Tempat Pelaksanaan

Pelaksaan kegiatan pengabdian masyarakat melalui jaringan dengan menggunakan channel youtube dan grup whatsapp di lingkungan Universitas Muhammadiyah Mataram.

b. Waktu Pelaksaan

Pelaksanaan pemberian video edukasi vaksin COVID-19 dilakukan pada hari Senin, 29 Maret 2021.

\section{HASIL DAN PEMBAHASAN}

Pengabdian masyarakat ini dibagi menjadi tiga tahap, yaitu pra kegiatan, pelaksanaan kegiatan, dan pasca kegiatan. Pada tahap pra kegiatan, telah dilakukan pemilihan sasaran kelompok, rancangan pembuatan video dimulai dari menentukan konten yang ada dalam video, rancangan gambar yang dibutuhkan, pembuatan video dalam bahasa Indonesia dan bahasa Inggris, serta penyimpanan video sebelum didistribusikan. Pelaksanaan kegiatan telah dilakukan dengan mengunggah video ke channel youtube fakultas ilmu kesehatan Universitas Muhammadiyah Mataram (FIK UMMAT) pada tanggal 29 Maret 2021. Sedangkan pasca kegiatan dilakukan dengan monitoring dan evaluasi pelaksanaan kegiatan. Monitoring dilakukan dengan cara memantau jumlah penonton dan berapa banyak yang menyukai video. Sedangkan evaluasi dilakukan dengan menerima saran melalui kolom komentar. Konten yang ada di dalam video mencakup mekanisme kerja virus COVID-19, gejala COVID-19, definisi vaksin, manfaat vaksin, konsep herd immunity, jenis vaksin, cara kerja vaksin
COVID-19, efek yang mungkin timbul setelah vaksinasi COVID-19 dan cara pengatasannya. Gambar yang ada di dalam video juga merupakan gambar yang mudah dipahami.

Pada gambar 1, terlihat bahwa video sudah terupload di akun youtube FIK UMMAT. Video dapat ditonton pada link https://www.youtube.com/watch?v $=\mathrm{kq} 17$ PLQDNnw (Bahasa Indonesia) dan link https://www.youtube.com/watch? $\mathrm{v}=\mathrm{itg} Z$ OHEVpX8 (Bahasa Inggris).

Gambar 2 menunjukkan bukti dilakukan share video melalui group whatsapp di lingkungan civitas akademika UMMAT.

Gambar 1:

Bukti upload video di channel youtube FIK UMMAT

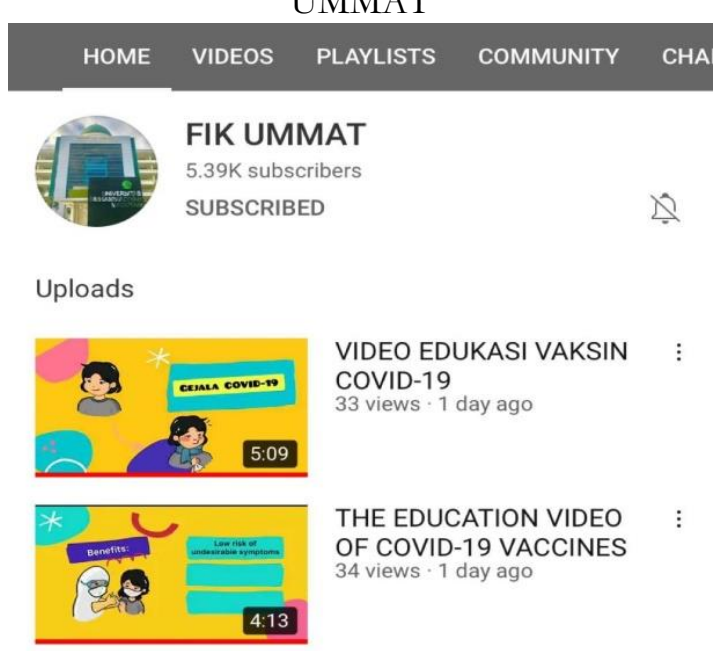


Gambar 2:

Bukti share video di beberapa group whatsapp

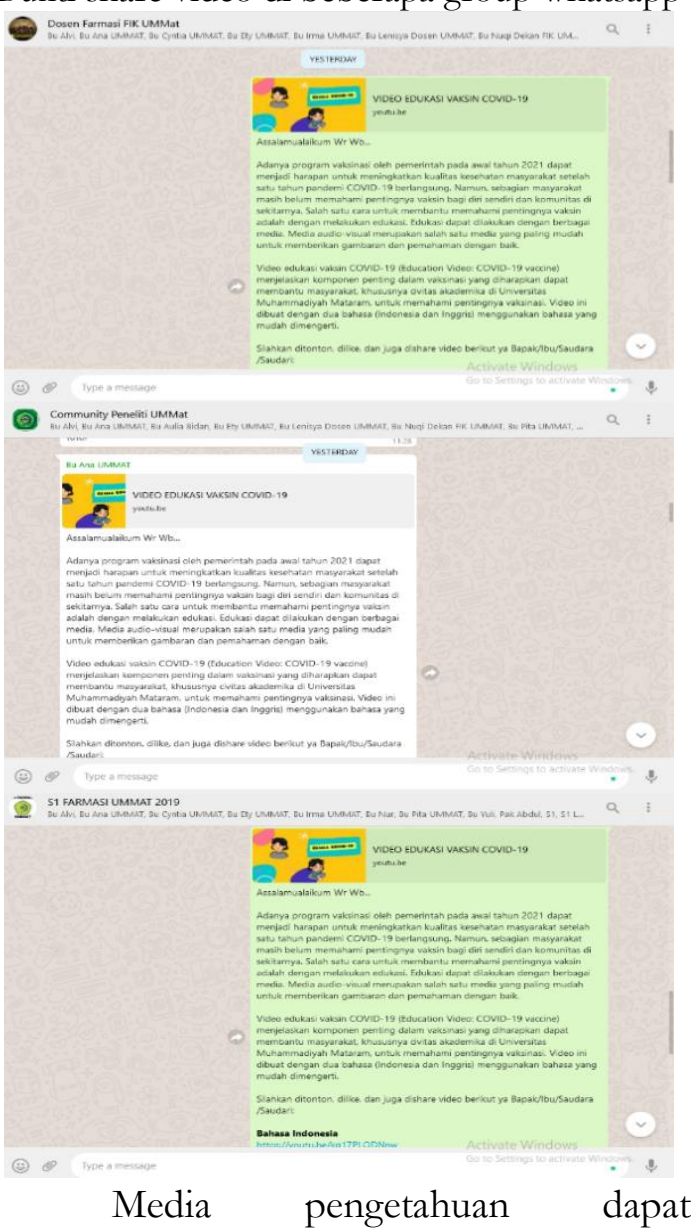

membantu dalam meningkatkan pengetahuan masyakarat akan pentingnya kesehatan. Media yang dikemas dengan inovasi dan kreatifitas yang tinggi dapat memberikan motivasi belajar yang lebih tinggi dibandingkan dengan pemberian pengetahuan tanpa media. Pemberian pengetahuan dengan cara yang lebih menarik dapat meningkatkan motivasi belajar masyarakat (Kantohe et al., 2016).

Berdasarkan hasil beberapa penelitian dicantumkan bahwa terdapat pengaruh pemberian pengetahuan terhadap peningkatan pemahaman masayarakat (Megawati, et. Al, 2014 dan Kumboyono, 2011 dalam Kantohe et al., 2016). Selain itu, pengetahuan merupakan salah satu determinan yang dapat membentuk sikap (Notoatmodjo, 2003), sehingga masyarakat dapat membentuk persepsi yang positif apabila telah memiliki pengetahuan yang cukup.

Pengetahuan tentang vaksin COVID-19 merupakan hal penting dilakukan guna untuk meminimalisir pemaparan COVID-19. Pengetahuan yang disampaian meliputi definisi vaksin, jenis vaksin, mekanisme vaksin, pengenalan vaksin COVID-19 dan hal-hal yang perlu dilakukan jika timbul efek samping (Sabarudin et al., 2020).

Media video online merupakan cara yang banyak digunakan di masa pandemic COVID-19 ini. Video online menjadi pilihan dalam peningkatan pengetahuan untuk membantu pemahaman dalam peningkatan pengetahuan mengenai vaksin COVID-19 (Kantohe et al., 2016). Selain itu, media video merupakan media yang memaksimalkan pendengaran dan pendengaran dari seseorang. Semakin banyaknya alat indera yang terlibat dalam menerima dan mengolah informasi, semakin besar kemungkinan isi informasi tersebut dapat dipertahankan dalam ingatan seseorang (Maulana, 2009). Salah satu konsep penyampaian edukasi, Multimedia Cone of Abstraction, juga menyampaikan bahwa media video sebagai media penyampaian edukasi merepresentasikan konten yang lebih realistis dibanding media lainnya (Baukal et al., 2013). Edukasi dalam bentuk video mengkombinasikan efek suara dan efek gambar, sehingga penyampaian ini dianggap sebagai salah satu cara yang paling efektif dan efisien.

Sasaran edukasi dapat diberikan link video melalui grup Whatssapp dan digunakan pada pria maupun wanita. Adapun kelemahan dari metode pemberian edukasi antara lain tidak dapat menjangkau sasaran keluarga yang tidak memiliki gawai jenis smartphone ataupun yang keluarga yang kurang memahami terkait teknologi. Metode lain yang dapat menjangkau sasaran 
secara luas dikenal dengan wawar keliling (Public Service Announcement). Metode edukasi seperti ini lebih efektif dalam memunculkan reaksi positif dari masyarakat (Surtimanah et al., 2021). Pada masa pandemi COVID-19 ini, pertimbangan pemberian video lebih menguntungkan dikarenakan video dapat menjangkau banyak sasaran tanpa perlu melakukan kontak secara langsung, sehingga dapat mencegah paparan COVID-19.

Video edukasi yang diberikan dapat digunakan sebagai media untuk meningkatkan kesadaran masyarakat. Video dapat dibuat dengan menggunakan beberapa aspek seperti infomasi, sikap dan psikologis masyarakat sehingga edukasi yang akan diberikan dapat diterima dengan baik oleh masyarakat (Surtimanah et al., 2021).

Keterbatasan dalam pengabdian masyarakat ini antara lain tidak dilakukan pengukuran terhadap pengetahuan civitas akademika di Universitas Muhammadiyah Mataram terakait vaksin COVID_19 sehingga tidak dapat diketahui efektivitas video terhadap peningkatan pengetahuan target sasaran. Namun, video ini merupakan salah satu upaya pemberian edukasi untuk meningkatakan pemahaman mengenai vaksin COVID-19 pada civitas akademika di Universitas Muhammadiyah Mataram.

\section{KESIMPULAN}

Melalui video edukasi, diharapkan civitas akademika dapat memperoleh pengetahuan mengenai pentingnya berpartisipasi dalam vaksinasi COVID-19. Edukasi perlu dilakukan secara berkelanjutan dalam upaya mewujudkan kesehatan masyarakat, khususnya pencegahan penyakit menular.

\section{DAFTAR PUSTAKA}

Baukal, C. E., Ausburn, F. B., \& Ausburn, L. J. (2013). A Proposed Multimedia Cone of Abstraction: Updating a Classic Instructional
Design Theory. I-Manager's Journal of Educational Technology, 9(4), 1524.

https://doi.org/10.26634/jet.9.4. 2129

Kantohe, Z. R., Wowor, V. N. S., \& Gunawan, P. N. (2016). Perbandingan efektivitas pendidikan kesehatan gigi menggunakan media video dan flip chart terhadap peningkatan pengetahuan kesehatan gigi dan mulut anak. E-GIGI, 4(2), 7-12. https://doi.org/10.35790/eg.4.2. 2016.13490

Maulana, H. D. (2009). Promosi Kesehatan. EGC.

Notoatmodjo, S. (2003). Pengantar Pendidikan Kesehatan dan Ilmu Perilaku. Andi Offset.

Radji, M. (2009). Vaksin Dna: Vaksin Generasi Keempat. Majalah Ilmu Kefarmasian, VI(1), 28-37.

Sabarudin, Mahmudah, R., Ruslin, Aba, L., Nggawu, L. O., Syahbudin, Nirmala, F., Saputri, A. I., \& Hasyim, M. S. (2020). Efektivitas Pemberian Edukasi secara Online melalui Media Video dan Leaflet terhadap Tingkat Pengetahuan Pencegahan Covid-19 di Kota Baubau. Jurnal Farmasi Galenika (Galenika Journal of Pharmacy) (eJournal), 6(2), 309-318. https://doi.org/10.22487/j24428 744.2020.v6.i2.15253

Surtimanah, T., Hanifah, H., Alfianita, D., Nataria, N., Syifa, S., Mulyawan, P., \& Sjamsuddin, I. N. (2021). Penyuluban Pencegahan Covid-19 Melalui Video Bagi Masyarakat Perdesaan dan Perkotaan Extension For Covid-19 Prevention Through Video For Rural and Urban Communities Program Studi Sarjana Kesehatan Masyarakat, dan 


\section{Pemerintah Indonesia melakukan \\ Penetapan . 1, 43-54.}

WHO. (2020). Listings of WHO's response to

COVID-19.

https://www.who.int/news/item

/29-06-2020-covidtimeline

Worldometers. (2020). Covid Coronavirus

Pandemic.

https://www.worldometers.info/

coronavirus/ 